\title{
Biomarkers of Psychological Stress in Health Disparities Research
}

\author{
Zora Djuric*,a, Chloe E. Bird ${ }^{\mathrm{b}}$, Alice Furumoto-Dawson ${ }^{\mathrm{c}}$, Garth H. Rauscher ${ }^{\mathrm{d}}$, Mack T. Ruffin IV \\ Raymond P. Stowe ${ }^{\mathrm{e}}$, Katherine L. Tucker ${ }^{\mathrm{f}}$ and Christopher M. Masi ${ }^{\mathrm{c}}$ \\ ${ }^{a}$ University of Michigan, Ann Arbor, MI; ${ }^{b}$ Rand Corporation, CA; ${ }^{c}$ University of Chicago, Chicago, IL; ${ }^{d}$ University of \\ Illinois, Chicago IL; ${ }^{e}$ Microgen Laboratories, La Marque, TX and ${ }^{f}$ Tufts University, Boston, MA, USA
}

\begin{abstract}
Psychological stress can contribute to health disparities in populations that are confronted with the recurring stress of everyday life. A number of biomarkers have been shown to be affected by psychological stress. These biomarkers include allostatic load, which is a summary measure of the cumulative biological burden of the repeated attempts to adapt to daily stress. Allostatic load includes effects on the hypothalamic-pituitary axis, the sympathetic nervous system and the cardiovascular system. These in turn affect the immune system via bidirectional signaling pathways. Evidence is also building that psychological stress, perhaps via heightened inflammatory states, can increase oxidative stress levels and DNA damage. The inter-relationships of ethnicity, genotype, gene expression and ability to adequately mitigate stress response are just starting to be appreciated. The need to conduct these studies in disadvantaged populations is clear and requires methods to address potential logistical barriers. Biomarkers can help characterize and quantify the biological impact of psychological stress on the etiology of health disparities.
\end{abstract}

Keywords: Psychosocial stress, health disparities, allostatic load, oxidative stress.

\section{INTRODUCTION}

Health disparities have been defined by the National Institutes of Health as "differences in the incidence, mortality and burden of diseases and other adverse health conditions that exist among specific population groups in the United States" [1]. The etiology of these health disparities is multifaceted and complex. While some factors, such as access to care clearly can affect health outcomes, the contribution of psychological stress to health and health disparities may be less obvious. Psychological stress can stem from factors at the individual-level, such as ability to cope with challenges, and at the social level, such as those stemming from various aspects of neighborhood environments and social circumstances [2]. This review discusses the sources of health disparities and parameters that can be measured in biological fluids to assess the effects of psychological stress on populations subject to health disparities.

\section{HEALTH DISPARITIES}

Health disparities translate to lower life expectancy, decreased quality of life, decreased productivity, increased health care costs and widening social inequities. If the disparities continue, the magnitude of the problem will grow as racial and ethnic minorities are expected to account for almost $50 \%$ of the U.S. population by 2050 [3]. A recent study indicates that between 1991 and 2000, five times as many lives could have been saved by ending health disparities than were saved by innovations in health technology over the same period [4].

*Address correspondence to this author at the University of Michigan, 1500 E. Hospital Drive, Room 2150 Cancer and Geriatrics Center, Ann Arbor, MI 48109-0930; USA; Tel: 734-615-6210; Fax: 734-647-9817;

E-mail: zoralong@umich.edu
There are many examples of health disparities in the U.S. Diabetes is twice as prevalent in American Indians and Alaskan Natives versus the general population, but these groups experience lower cancer mortality than the general U.S. population for all cancers except stomach and liver [5]. Death rates from cardiovascular disease are highest in blacks, followed by whites and Hispanics with the lowest rates being observed in Asian or Pacific Islanders, American Indians and Native Alaskans [6]. "Years of potential life lost" are greater in non-Hispanic blacks than whites for human immunodeficiency virus (HIV) infection, tuberculosis, homicide, stroke, perinatal disease and diabetes $[7,8]$. Hispanics also experience more years of life lost due to disease compared to non-Hispanic whites for HIV infection, homicide, liver disease, diabetes and stroke [9]. Obesity, which is a cause of many health risks, is more prevalent in certain racial/ethnic groups independent of SES [10, 11]. Recently, the top ten largest health disparities have been published for the major ethnic groups in the United States, and the magnitude of the differences in disease incidence by ethnicity or race is astounding, especially for syphilis, gonorrhea and AIDS in blacks versus whites [12].

With regard to cancer, data from the National Cancer Institute's Surveillance, Epidemiology and End Results (SEER) Program (1996-2000) shows that cancer mortality was higher and cancer survival lower in residents of lowerincome areas [13]. However, after poverty was accounted for, both cancer incidence and mortality differed across racial and ethnic groups. Mortality from cancers of the colorectum, lung and bronchus, cervix and prostate was higher in African Americans than in any other racial/ethnic group. Breast cancer incidence was highest in whites, but mortality was greatest in African Americans. Asian and Pacific Islanders had the highest incidence and mortality of stomach and liver cancers (except for stomach cancer mortality in males 
which was highest in African Americans). Remarkably, Native Americans, Asian/Pacific Islanders and Hispanics had lower cancer incidence and mortality overall than African Americans or non-Hispanic whites [13].

Potential causes of these health disparities are multiple, as shown in Fig. (1). McGinnis et al. have reviewed causes of premature mortality and classified them into five domains: genetic and gestational endowment, social circumstances, environmental conditions, behavioral choices, and shortfalls in medical care [14]. To this model we add psychological stress which can have strong effects on health, in both positive and negative ways [14]. For example, perceived breast cancer incurability was associated with higher overall mortality in a small prospective cohort of African American and white women [15]. In the same cohort, stronger perceived emotional support showed a significant association with increased survival time [16]. In the Black Women's Health Study, women who reported racial discrimination were at increased risk for breast cancer [17]. Many studies provide evidence that perceptions of social challenges and difficulties (e.g., racism, life events, family interactions) are related to adverse physiological changes in African Americans [1823]. More broadly, situations that damage well-being are differentially distributed in the population not only by race/ethnicity but also by socio-economic status and gender (for example, [24-26]).

\section{PHYSIOLOGICAL EFFECTS OF PSYCHOLOGICAL STRESS}

The term homeostasis was coined by Cannon to describe the stability of physiologic systems in living organisms [27]. A related term, allostasis, refers to an organism's ability to respond to physical and psychological demands through activation of various physiologic processes [28]. Such responses can be life-preserving, to prepare the body for intense physical activity such as running or fighting. Repeated activation of allostatic systems, however, can have a physiologic cost and may lead to increased risk of chronic disease, including hypertension, obesity, atherosclerosis, and cognitive decline, ultimately increasing morbidity and mortality $[29,30]$.

"Allostatic load" refers to the cumulative biological burden exacted on the body through daily adaptation to physical and emotional stress [31]. A summary measure of this load, as developed in the MacArthur Aging Studies, is based on biomarkers of biological functioning including the hypothalamic-pituitary-adrenal (HPA) axis (serum dehydroepiandrosterone sulfate (DHEA-S, a functional antagonist of cortisol [32], and urinary cortisol); the sympathetic nervous system (urinary norepinephrine and epinephrine); the cardiovascular system (systolic and diastolic blood pressure, serum high-density lipoprotein (HDL) and total cholesterol concentrations); metabolic processes (plasma glycosylated hemoglobin, a measure of glucose levels over time); and waist/hip ratio (which is related to hormonal balance and fat metabolism). Each parameter is assigned a binary score, with adverse values given a higher score, and the individual scores are summed to give an overall allostatic load score. Geronimus et al. found that differences in allostatic load scores between blacks and whites in the U.S. were independent of poverty, supporting the notion that the "weathering effects of living in a race-conscious society" contribute to health disparities [33].

One factor that has often been overlooked in studies of allostatic load is nutrition (Fig. 2) [34]. Under conditions of high stress, individuals consume significantly more dietary fat and fewer micronutrients [35]. Consumption of high glycemic index foods may increase risks for obesity, type 2 diabetes and heart disease [36]. Nutrition can also interact with stress in contributing to cognitive decline in the elderly [34]. Conversely, vitamins and antioxidants may help ameliorate allostatic load. Results from the Dietary Approaches to Stop Hypertension (DASH) study indicated that plasma vitamin C levels were inversely correlated with diastolic blood pressure, and that changes in diet affected blood pressure within 30 days [37-39]. With regard to artherogenesis, antioxidants may exert their beneficial effects by inhibiting oxidation of low-density lipoprotein and other free radical reactions [4042]. While stress can affect dietary habits, allostatic load may additionally affect nutrient status through nutrient oxidation/destruction, resulting in further immunosuppression and impairment of regulatory systems, contributing to a greater disease burden (Fig. 2).

\section{STRESS HORMONES}

\section{Anatomy and Physiology of the Stress Response}

Psychological stress leads to a cascade of physiological events including activation of the sympathetic nervous sys-

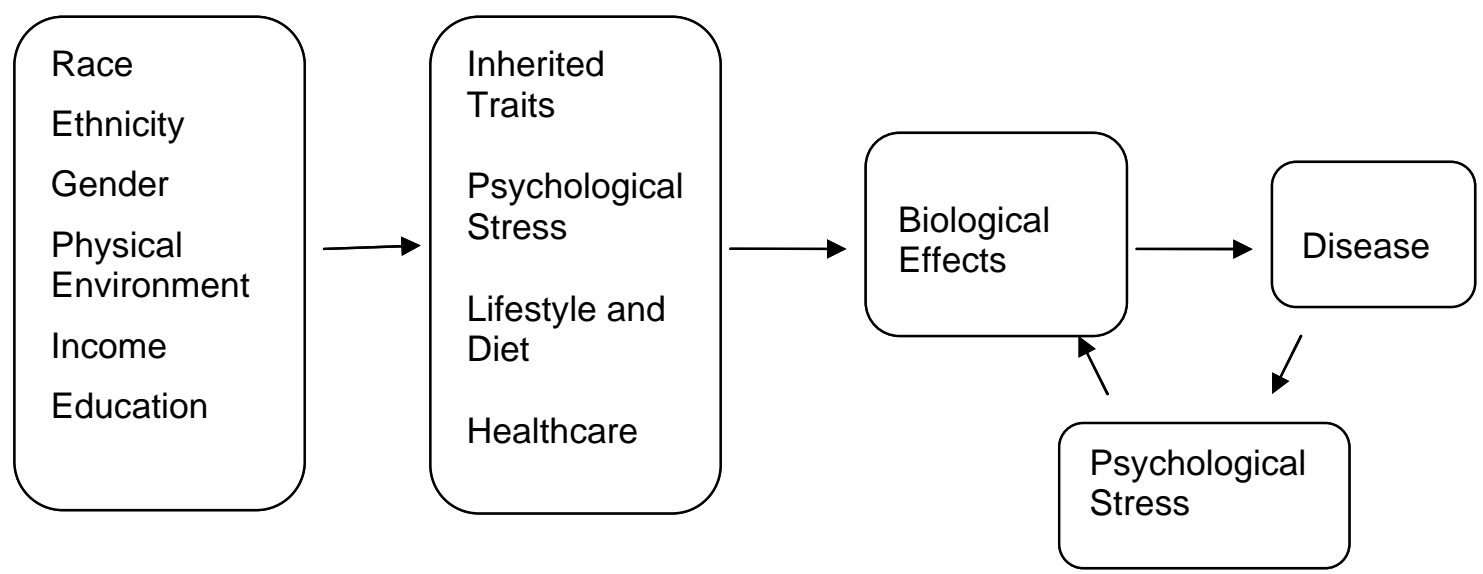

Fig. (1). Causes of Health Disparities. Shown are some of the factors that can act independently as well as interactively to result in differential health status in various population groups. 


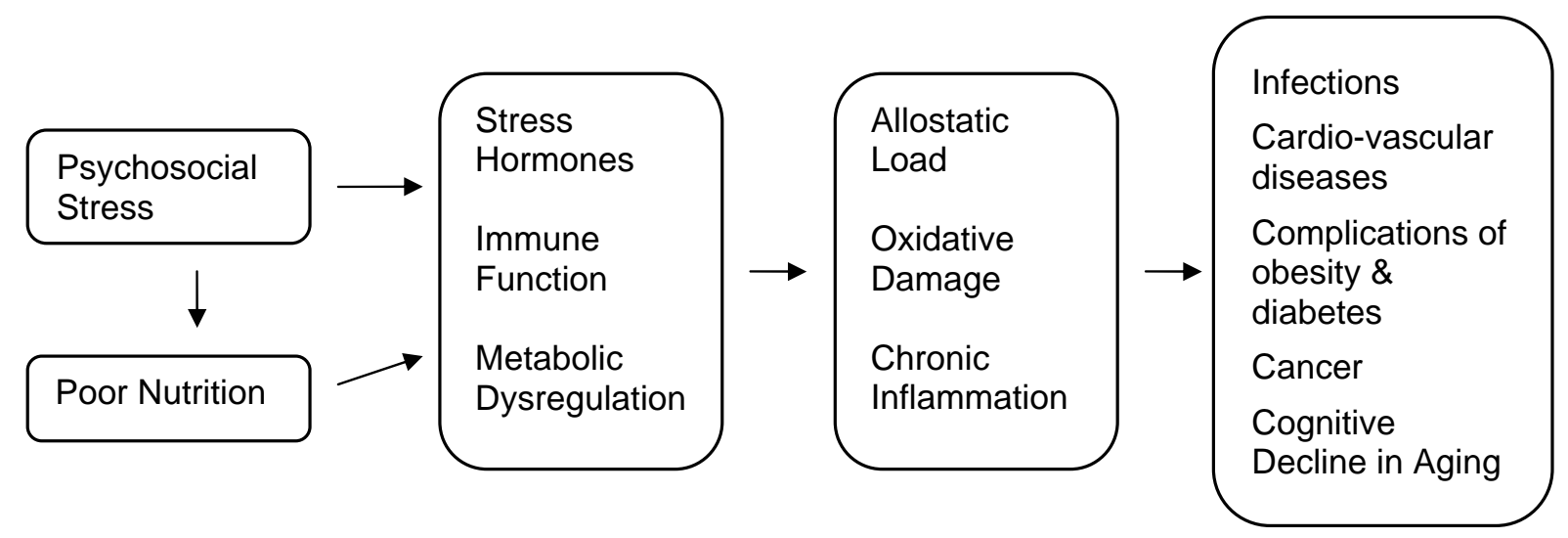

Fig. (2). Possible physiological mediators of psychosocial stress.

tem and the HPA axis. These systems operate in coordination when situations which provoke fear or anxiety are encountered. The hypothalamus releases corticotropin releasing hormone $(\mathrm{CRH})$ when stimulated. $\mathrm{CRH}$ then reaches the anterior pituitary glad via the hypophyseal portal circulation and the locus ceruleus via projections from the hypothalamic PVN [43]. The locus ceruleus is one of several nuclei in the brainstem that serve as hubs of sympathetic activity. Activation of these centers results in stimulation of target organs through direct sympathetic innervation as well as through circulating catecholamines (epinephrine and norepinephrine) released from the adrenal medulla.

Psychological stress is a potent stimulator of epinephrine production while norepinephrine output is more closely associated with physical activity and body posture [44]. The effects of circulating catecholamines on target organs are the same as those of direct sympathetic nerve stimulation (pupil dilation, increased heart rate, increased blood flow to skeletal muscles, etc.) but the effects last 5 to 10 times as long because circulating epinephrine and norepinephrine are removed from the blood over several minutes. In addition, circulating epinephrine and norepinephrine from the adrenal medulla increase the metabolic rate of all cells in the body, most of which are not innervated by sympathetic fibers [45].

$\mathrm{CRH}$ in the anterior pituitary causes adrenocorticotropin hormone $(\mathrm{ACTH})$ release into the systemic circulation. Upon reaching the adrenal gland, ACTH stimulates the production of glucocorticoids (e.g. cortisol) as well as aldosterone and adrenal androgens. In the stress response, cortisol has multiple effects, including negative feedback on CRH and ACTH, maintenance of blood glucose levels, and enhanced activity of catecholamines at target tissues [46-48]. The adrenal cortex secretes cortisol in a diurnal pattern which helps control several biological processes, including systemic blood pressure, carbohydrate, protein, and lipid metabolism, salt and water homeostasis, and bone and calcium metabolism [48, 49]. Cortisol can enhance the immune response while many other glucocorticoid and catecholamine effects are immunosuppressive. This has led to the hypothesis that stress hormones help control the immune response by preventing an exaggerated response to antigens [46, 50, 51].

\section{Changes Associated with Chronic Stress}

Enhanced production of cortisol and catecholamines enables humans to respond to real and perceived threats, but excessive activation of the SAM and HPA axes has been associated with negative biological effects. For example, cortisol stimulates deposition of visceral or abdominal fat [52] and chronic stress is a risk factor for obesity [53]. Glucocorticoid excess adversely affects muscle and skin via atrophy and reduced collagen production, respectively, [54] and also leads to osteoporosis via osteoblast inhibition [55]. Effects of glucocorticoid excess on the central nervous system include neuronal death in the hippocampus [56], depression, apathy, and cognitive decline [48]. Glucocorticoid receptors are present throughout the body, mediating a myriad of effects including induction of liver enzymes involved in energy metabolism; regulation of immune cells and cytokine production, and the formation of fear-related memories [31, 57].

While recurrent activation of the stress response is normal, the cost of repeated stress hormone elevation is wear and tear on physiological processes and organ systems. This wear and tear, or allostatic load, is considered a risk factor for several diseases, including atherosclerosis, coronary heart disease, obesity, diabetes, depression, cognitive impairment, and both inflammatory and autoimmune disorders [29]. For example, recurrent severe stress early in childhood may lead to cellular and physiologic changes that persist into adulthood. Heim et al. found that women with a history of childhood physical and/or sexual abuse exhibited increased peak ACTH levels compared to controls in response to a psychosocial stress (public speaking) [58]. In another study, adults with low childhood socioeconomic status (SES) had higher rates of ischemia on exercise stress tests compared to adults with high childhood SES, after controlling for current SES, smoking history, and ratio of HDL to LDL cholesterol [59]. Chronic mild stress leads to increased trough levels of plasma cortisol while chronic severe stress results in around the clock elevations in both plasma ACTH and cortisol [60].

Chronic elevation of catecholamine levels are thought to contribute to hypertension, atherosclerosis, and coronary artery disease, as well as disorders associated with blood clotting, including ischemic stroke and myocardial infarction [44]. Elevated plasma epinephrine has also been associated with mortality and functional decline in high-functioning older adults [61], as well as poor survival in patients with previous myocardial infarction [62] while increased plasma norepinephrine has been associated with mortality in healthy 
older adults [63], congestive heart failure [64], and previous myocardial infarction [62].

\section{Hormonal Measures of Stress}

Given the central role of cortisol and catecholamines in the stress response and their association with stress-related illnesses, it is not surprising that studies of stress and health often include assessment of these hormones. Once released from the adrenal cortex, cortisol is rapidly bound to corticosteroid-binding globulin (CBG), albumin, and erythrocytes. As a result, only $2-15 \%$ of cortisol is unbound or free. It is this fraction that is thought to mediate the multiple effects of cortisol on peripheral and brain tissues. Both bound and free cortisol can be measured in blood but only free cortisol can be measured in saliva [65]. Plasma and salivary cortisol reflect real-time circulating cortisol while urinary cortisol reflects cortisol production over time. For saliva collection, study participants simply place saliva in a small container or chew on a cotton swab (Salivette) and then place the swab into a small container. Saliva collected in this way can be stored at room temperature for at least 4 weeks without a significant reduction in cortisol concentration. Most laboratories test saliva concentration using immunoassays with radioactive or other tracers. Salivary cortisol accurately reflects unbound cortisol in blood and can be used as a less invasive biomarker $[65,66]$.

Urinary cortisol is frequently measured by 24 -hour urine collection or as part of an overnight collection protocol. 24hour urine collection is more onerous compared to overnight urine collection, but the results are less influenced by the sleep-wake cycle and timing of collection initiation. Because of individual differences in hydrations status and urine production, urine concentration must be accounted for when calculating the concentration of urinary hormones. Dividing urinary hormone concentration by urinary creatinine concentration is the most common method of correcting for urine concentration [67]. However, because creatinine production is influenced by muscle mass and race/ethnicity [68], this approach can lead to falsely lower values among certain groups, including males and African Americans [69].

Catecholamine assessment can also be conducted using plasma, urine, or saliva samples. Good correlations have been found between changes in plasma and urinary catecholamines in response to stress [44]. In contrast, salivary catecholamine levels do not parallel those in plasma [70]. Because catecholamines are influenced by posture, physical activity, and venipuncture, concerns have been raised regarding the validity and reliability of plasma catecholamines as biomarkers $[62,71]$. In contrast, urine collection for catecholamine assessment is painless and does not interfere with the normal habits and environment of study participants. Urinary assays therefore offer an accurate reflection of epinephrine and norepinephrine production over time. During mild stress, such as that associated with normal daily work, epinephrine production may increase by $50-100 \%$ above basal production. With more severe psychological stress, epinephrine may rise to eight to ten times the basal level [44].

Urinary catecholamines are often reported as total amount over 24 hours, which is calculated by multiplying hormone concentration by the 24-hour urine volume. Once urine is obtained, the $\mathrm{pH}$ of should be adjusted to 3.0 using acid to prevent catecholamines from degrading. In addition, acidified urine samples should be kept frozen until analyzed. The most common method for assaying urine or blood catecholamines is high-performance liquid chromatography with electrochemical detection [44]. In addition to posture and physical activity, several confounders should be considered when measuring catecholamines, including use of caffeine, alcohol, nicotine, and medications, including $\beta$ blockers and diuretics.

\section{THE IMMUNE SYSTEM}

\section{Stress-Related Immune Alterations}

A bidirectional communication exists between the central nervous and immune systems which involves common peptide hormones and receptors that regulate the immune response via feedback mechanisms [72-74]. The hypothalamus has a central role in coordinating the endocrine, autonomic, and behavioral responses to stress [72-74]. The end product of HPA stimulation was shown to be glucocorticoids by Smith et al. [75], who demonstrated that adrenocorticotropic hormone stimulated the release of cortisol from the adrenal cortex. Glucocorticoids affect the immune system by altering leukocyte trafficking and migration of various cell types to areas of inflammation as well as directly inhibiting individual cellular functions. Corticosteroid administration rapidly induces neutrophilia, or excess neutrophil production [76, 77]. Lymphocyte number in peripheral blood decreases owing to retention of recirculating lymphocytes within the bone marrow, spleen, and lymph nodes; a transient monocytopenia with kinetics similar to those of lymphocytes have been reported after corticosteroid administration [76, 77]. These shifts in leukocyte subpopulations may represent a mechanism to avoid detrimental effects of stress or alternatively prepare the immune system for encounters with antigens and pathogens [78].

Glucocorticoids are primarily anti-inflammatory in that they inhibit interleukin (IL)-12 production and increase IL10 production by monocytes [79-82]. This drives the immune response towards a Th2 cytokine profile (characterized by production of IL-4, IL-5, and IL-10 which elicit humoral immunity) and away from a Th1 profile (production of IL-2, IL-12, and IFN- $\alpha$ which elicits cellular immunity), which may be mediated by the transcription factor NF-kB [83-85].

Catecholamines also affect immune status and enhance the proliferation of $\mathrm{CD} 3+, \mathrm{CD} 4+$, and $\mathrm{CD} 8+$ lymphocytes by $\beta$-adrenergic stimulation, whereas adrenergic stimulation (via intracellular adenylate cyclase) inhibits lymphocyte proliferation [86-88]. Injection of epinephrine causes a decrease in the percentage of $\mathrm{CD} 4+$ lymphocytes and an increase in the percentage of NK cells, and variable results for the CD8+ lymphocytes; no change was observed in monocytes or Blymphocytes [89]. Epinephrine produces a profound effect on circulating neutrophil number by causing a demargination of neutrophils adhering to the vascular endothelium, while cortisol achieves this effect by release of neutrophils from the bone marrow reserve and increasing their half-life [90]. Norepinephrine has been shown to completely block IFN- $\alpha$ activation of peritoneal macrophages to a tumoricidal state [91].

The overall effects of chronic stress on immune modulation are therefore diverse and include decreased NK 
cell function, down-regulation of T- and B-cell responses, an imbalance in cytokine production (e.g., Th1 $\rightarrow$ Th2 shift), delayed wound healing, and impaired antibody response after vaccination [92]. Stress may also be linked to the induction of proinflammatory cytokines such as IL-6. Kiecolt-Glaser et al. [93] found increased levels of plasma IL-6 in aged caregivers as compared to noncaregivers, which may partially explain the much greater incidence of all-cause mortality among this group [94]. IL-6 levels are also higher in individuals with poor health habits such as smoking, poor diet, low physical activity, and higher BMI [95-97]. Notably, IL-6 induces C-reactive protein (CRP) by the liver, and IL-6 and CRP together are important in the process that leads to the development of cardiovascular disease [98-103]. Consistent with the concept of allostatic load, inflammation is also likely to become more chronic when faced with repeated stressors [104]. Recent studies have increasingly shown that measures of inflammation are contributors to health risks $[105,106]$.

Chronic stress may also affect the immune system by altering telomere length and telomerase activity, two markers associated with aging. Epel et al. [107] found that mothers who were caring for chronically ill children had shorter telomeres and lower telomerase activity in peripheral blood mononuclear cells than mothers who cared for healthy children. In addition, chronic stress in this group was associated with higher oxidative-stress activity as measured by levels of $\mathrm{F}_{2}$-isoprostanes. There is a growing literature that oxidative DNA damage is involved in telomere shortening [108]. These data, together with the stressassociated increases in IL-6, could provide a mechanism through which chronic stress may prematurely age the immune system and could enhance the risk of illness as well as age-related diseases.

\section{Impact of Chronic Stress on Viral Infections}

In agreement with studies demonstrating impaired vaccine responses, stress has also been shown to increase susceptibility to infection with common respiratory viruses [109]. Moreover, the incidence of infections was greater in individuals who had a higher number of recent stressful life events or those whose stressors were a month or longer in duration [110, 111]. Lower levels of socioeconomic status (SES) were associated with greater risk of viral-induced illnesses during adulthood, suggesting a direct role of stressful environment on health disparities [112]. A recent review has indicated that the top sources of health disparities in African Americans, Hispanics and Asians in the United States include gonorrhea, syphilis, AIDS and tuberculosis [12].

HIV/AIDS disproportionately affects minority races and ethnicities in the United States. Dean et al. [113] investigated HIV/AIDS data reported by the CDC and found that AIDS diagnosis was consistently higher among nonHispanic blacks than among other races and ethnicities. Stress also increases the rate of disease progression in HIVinfected men. In a longitudinal study of HIV-infected males who were asymptomatic early on, faster disease progression correlated with more stressful life events and less social or interpersonal support [114]. AIDS progressed faster in HIVpositive men who concealed their homosexuality as compared to those who did not [115]. Notably, latent viruses such herpes viruses are not cleared by the host after infection but remain latent after primary infection, and reactivation of these latent viruses may serve as a biological marker of stress and immune dysregulation.

\section{OXIDATIVE STRESS}

Oxidative stress is related to the immune response in many ways. One of the functions of inflammatory cells is to produce reactive oxygen species as part of their normal function in combating infections and injury. Production of reactive oxygen species in turn recruits more inflammatory cells. Reactive oxygen species and lipid oxidation products may in fact act as intra- and inter-cellular messengers [116]. However, in addition to acute responses, a state of increased inflammation and oxidative stress, or imbalance between the production of oxidants and their detoxification, can also be a chronic condition. For example, a state of chronic low-grade inflammation (e.g., inflammatory bowel disease, diabetes), and the resulting oxidative stress has been implicated in risk of various cancers [117-119]. Measures of C-reactive protein (CRP), a marker of inflammation, have been recommended as being useful in identifying cardiovascular risk in otherwise healthy individuals [120].

Oxidative stress has been shown to play a role in the major chronic diseases that are faced today. With regard to cardiovascular disease, excess generation of oxidants can result in lipid peroxidation, which is involved in plaque formation, can impair vascular tone via destruction of nitric oxide and can directly damage the vasculature [121-125]. Oxidative stress also has a role in the complications of diabetes including retinopathy, renal disease and vascular injury [126-128]. With regard to cancer risk, oxidants can damage critical cellular macromolecules including DNA, and oxidative DNA damage that is not repaired can result in mutations and transformation of cells to the cancerous state, as shown in Fig. (3) [129].

\section{Effects of Race and Ethnicity on Oxidative Stress}

Oxidative stress is emerging as an important factor in the pathogenesis of cardiovascular diseases, which disproportionately affect African Americans [125, 130]. Oxidative stress plays a role in endothelial dysfunction via destruction of nitric oxide (NO), a potent vasodilator [124]. Oxidative stress levels do not appear to be higher in African Americans than whites [131], but regulation of NO appears disrupted due to excessive O2- and ONOO-generation [132]. Human umbilical vein endothelial cells from blacks exhibit a nitric oxide/oxidant steady state that is closer to that associated with impaired endothelial function than cells from whites, with relatively reduced release of nitric oxide and increased release of superoxide and peroxynitrite in blacks [133]. In blacks, but not in whites, lipid peroxidation appeared to mediate the relationship between body mass index, aldosterone levels and systolic blood pressure [134]. Similarly, although baseline plasma levels of one marker of lipid peroxidation, $15-\mathrm{F}_{2 \mathrm{t}}$-isoprostane, did not differ between African Americans and white Americans, the increase in $15-\mathrm{F}_{2 \mathrm{t}}$-isoprostane in response to acute hyperlipidemia was markedly greater in African Americans [135]. In women, 15- $\mathrm{F}_{2 \mathrm{t}}$-isoprostane levels did not differ by race but hormonal therapy induced NO release in Caucasians but not in African Americans [136]. 
Cancer incidence and survival also differs by race. For example, black and white American women have higher rates of breast cancer than Hispanic, American Indian and Asian American women [137]. Once cancer develops, prognosis has been shown to be worse in African Americans versus European Americans for prostate, breast, lung and colon cancer, which are the major cancers affecting the U.S. population today [138-142]. Multiple mechanisms could account for differences in cancer risks and survival, but oxidative stress is one important factor to consider. A large body of data supports a link between oxidative damage to the genome and increased cancer risk [129].

\section{Effects of Psychological Stress on Oxidative Stress Levels}

Both individual level and social level factors have been shown to contribute to oxidative stress. Immunological and hormonal factors described in preceding sections have been well-studied, but there is a growing literature on the effects of psychosocial stress on oxidative stress levels as well. Psychosocial stress increases oxidative stress via activation of $\mathrm{NF}-\kappa \mathrm{B}$, an inflammatory mediator [143]. In a cross-sectional study, psychological stress was correlated with increased Creactive protein and homocysteine levels, and homocysteine has been shown to increase production of reactive oxygen species [144, 145]. Homocysteine also increased with either anger experience or anger suppression [145]. Rats exposed to social stress had increased levels of corticosterone and in urinary excretion of biopyrrin, oxidized metabolites of bilirubin [146]. University students on the day of exams had significantly increased oxidative DNA damage, decreased antioxidant levels and increased sensitivity to lipid oxidation in lymphocytes versus on non-exam days [147]. Fear also can play a role. Conditioning of rats to a painful stimulus results in increased levels of deoxyguanosine oxidation (with formation of 8-oxo-2'-deoxyguanosine) in nuclear DNA from the kidney upon receipt of the conditioning stimulus without pain [148].

In addition to acute stressors, psychological disturbances, which can stem from chronic stress, have been related to oxidative damage. In females, but interestingly not in males, depression scores were correlated with levels of $8-\mathrm{OHdG}$ in leukocytes $[149,150]$. This was similarly observed in another cross-sectional study of females where levels of lipid peroxides in serum correlated positively with depression scores on the CES-D [151]. Urinary excretion of oxidized metabolites of bilirubin was increased in patients with psychiatric disorders relative to healthy volunteers [152]. This is of significance in health disparities research since depression and other psychological disorders differ in specific population groups defined by race/ethnicity or SES [153-159].

Social factors such as isolation, exposure to violence, noise, discrimination and racism also can contribute to oxidative stress. Some of these studies have been done in animal models. In rats, chronic stress in the form of long-term social isolation activated antioxidant enzymes (superoxide dismutase and catalase) in the hippocampus and affected subsequent response to acute stress [160]. In that study, oxidant generation was not measured, but induction of antioxidant enzymes likely stems from increased oxidative load. Psychological stress and noise stress in rats increased levels of lipid peroxidation $[161,162]$. One of the first papers to be published in this area used a communication box and showed that 8-oxodG levels were higher in rat liver nuclear DNA after exposure to psychological stress [163]. In humans, parental closeness in childhood was inversely related to 8oxodG levels in adults, and 8-oxodG levels were relatively higher in persons who experienced death of a close family member in the last 3 years [164].

In an interesting study conducted in Mexico, elderly persons living in urban areas had higher oxidative stress (and higher risk of cognitive impairment) versus elderly subjects living in rural areas who were similarly healthy and participated in equivalent amounts of exercise [165]. Oxidative stress in that study was measured by plasma antioxidant ability (ABTS), red cell superoxide dismutase, glutathione peroxidase, and plasma lipid peroxides (TBARS). Interestingly plasma TBARS were higher in elders with impaired cognitive status but rural/urban differences persisted in both groups with higher TBARs in the urban subjects. This was associated with an almost 5-fold higher risk of developing cognitive impairment in urban areas [166].

Effects of workplace stress on oxidative stress have only been examined in a few papers. In healthy Japanese females, perceived workload, perceived stress, the impossibility of alleviating stress and poor stress coping were all significantly associated with increased levels of 8-hydroxy-2'deoxyguanosine in leukocytes $[167,168]$. Interestingly, jobrelated "burnout" was related with increased tumor necrosis factor alpha $(\mathrm{TNF} \alpha)$ and glycosylated hemoglobin A (HbA1c), which is indicative of oxidative stress [169]. Longer work hours in train drivers were associated with increased frequency of health symptoms, but this association was only true in the absence of social support [170].

\section{The Role of DNA Repair on Oxidative Damage Levels}

DNA damage that is not efficiently repaired may be a key mechanism that mediates health disparities in cancer risk (Fig. 3). Reactive oxygen species react with DNA producing oxidative base damage, and the majority of this damage is repaired by the base excision repair pathway. Common forms of DNA damage include damage to guanine bases in the form of either 8-oxoguanine (8oxoG) or 8-hydroxy-2'deoxyguanosine (80xodG), both of which are highly mutagenic [171, 172]. Damage to thymine bases by oxidative stress most typically occurs in the formation of thymine glycol, another common DNA lesion that is highly mutagenic [173]. The impact of a given level of oxidative stress will depend on the capacity of this system to repair oxidative damage.

Base excision repair begins with removal of the damaged base by one of several damage-specific glycosylases [174]. In addition to removing the damaged base, the glycosylase nicks the DNA strand 3' from the lesion, creating an abasic (AP) site. The apurinic/apyrimidinic endonuclease APE1 initiates repair of the abasic (AP) sites by hydrolyzing the phosphodiester backbone immediately $5^{\prime}$ to the AP site [175]. DNA polymerase beta and DNA ligases I and III are involved in the latter stages of base excision repair, filling in the missing base and sealing the DNA strand [172]. The Xray repair cross complementing 1 (XRCC1) protein interacts with several other base excision repair proteins during the process of oxidative base excision repair [176]. Interestingly 

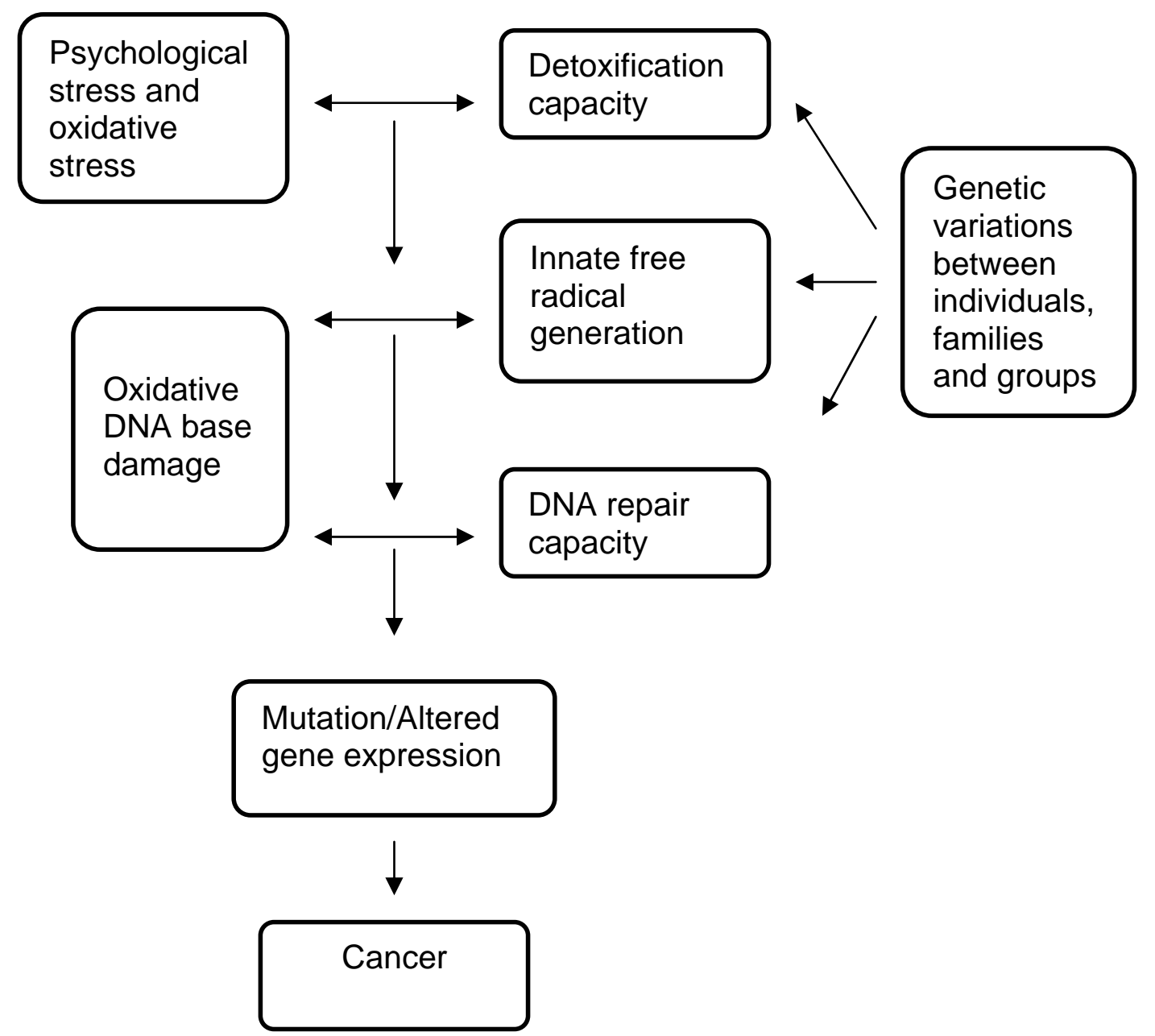

Fig. (3). Pathways in oxidative DNA damage and cancer risk. Genetic differences in susceptibility to the DNA damage from oxidative stress could produce disparities in disease burden when levels of stress are equivalent.

polymorphic variants in XRCC1 and APE1 were significantly associated with prostate cancer in white men but not in black men [177]. Among African American women, the association of breast cancer and smoking was strongest among women with specific combinations of nucleotide excision repair genotypes while no interactions with smoking were observed in white women [178]. Other genes are continually being discovered (eg. NTHL1, PNKP, NEIL1, NEIL3, APE2, OGG2, BRCA1 and 2) and appear to play a role in oxidative base-excision repair.

Nonsynonymous, single nucleotide polymorphisms have been identified in the coding regions of most of these genes, generally with unknown impact on the structure and binding properties of the enzyme. The 8-oxo-guanine glycosylase OGG1 contains a single prevalent, non-synonymous SNP at codon 326 (Ser to Cys). In vitro studies have implicated the variant SNP in increased oxidative DNA damage $[179,180]$. Epidemiologic data are sparse but suggest an increased cancer risk with the 326 variant [180-183]. XRCC1 has been more extensively studied; there are three prevalent, nonsynonymous SNPs at codons 194 (Arg to Trp), 280 (Arg to His) and 399 (Arg to Gln) [184]. All three SNPs lie in evolutionarily conserved regions near (but not within) binding sites for other base excision repair proteins [185], and alter the efficiency of the protein [186]. The few published studies of XRCC1 SNPs and breast cancer have not produced a clear picture of which of these SNPs confers increased breast cancer risk $[176,187-189]$. The APE gene contains a single prevalent ( $>5 \%$ population frequency), non-synonymous SNP at codon 148 (Asp to Glu) which has been linked to prolonged cell cycle delay [190], sensitivity to ionizing radiation [190], and lung cancer risk [191]. PARP1 has a single prevalent non-synonymous SNP at amino acid position 762 (Val to Ala), which is located in one of the more evolutionarily conserved regions of the gene [192]. XPG contains two prevalent, non-synonymous SNPs at codons 529 (Cys to Ser) and 1104 (Asp to His). Both alleles have been observed more frequently in African-Americans [184]. A single study estimated a $50 \%$ increased breast cancer risk associated with being either heterozygous or homozygous for the variant SNP at codon 1104 [193].

In addition to DNA repair, genes coding for enzymes that quench free radicals may also play a role in differential susceptibility to oxidative damage by race. Several enzymes such as the glutathione-S-transferases and those of the superoxide dismutase family, quench free radicals and remove them from the pool of potential DNA-damaging agents. Manganese superoxide dismutase (MnSOD) is one of three enzymes that functions in the first step of superoxide detoxification. A subsutitution of Valine for Alanine at position 9 
Table 1. Logistic Issues Associated with Biological Sampling for Biomarkers of Stress

\begin{tabular}{|c|c|c|c|c|c|}
\hline $\begin{array}{l}\text { Type of } \\
\text { Sample }\end{array}$ & Examples of Biomarkers & Sampling Notes & Immediate Processing & Storage & Shipping \\
\hline Urine & $\begin{array}{c}\text { Epinephrine/norepinepherine } \\
\text { Catecholamines } \\
\text { Cortisol }\end{array}$ & $\begin{array}{l}\text { 24-hour urine } \\
\text { collection is } \\
\text { onerous }\end{array}$ & $\begin{array}{l}\text { Freeze within } 2 \text { hours for } \\
\text { some assays such as } \\
\text { Catecholamines }\end{array}$ & $\begin{array}{l}\text { Frozen, generally at } \\
-70^{\circ} \mathrm{C} \text { but short } \\
\text { term storage at } \\
-20^{\circ} \mathrm{C} \text { is acceptable }\end{array}$ & Dry ice \\
\hline $\begin{array}{l}\text { Processed } \\
\text { whole blood }\end{array}$ & $\begin{array}{c}\text { Glycosylated hemoglobin } \\
\text { Oxidative damage } \\
\text { Genotype }\end{array}$ & $\begin{array}{l}\text { Fasting samples } \\
\text { are often } \\
\text { required, } \\
\text { requires a } \\
\text { centrifuge and } \\
\text { processing } \\
\text { solutions }\end{array}$ & $\begin{array}{l}\text { For markers of oxidative } \\
\text { stress freeze right away } \\
\text { and antioxidants may be } \\
\text { required for processing. } \\
\text { For glycosylated } \\
\text { hemoglobin, home test } \\
\text { strips are possible. }\end{array}$ & Frozen & Dry ice \\
\hline $\begin{array}{l}\text { Whole blood } \\
\text { dried on filter } \\
\text { paper }\end{array}$ & $\begin{array}{c}\text { C-reactive protein } \\
\text { Cortisol } \\
\text { Interleukins } \\
\text { DHEAS } \\
\text { Glucose } \\
\text { Glycosylated hemoglobin } \\
\text { insulin }\end{array}$ & $\begin{array}{l}\text { Proper spotting } \\
\text { technique } \\
\text { required }\end{array}$ & Minimal & $\begin{array}{l}\text { Room temperature } \\
\text { for short duration, } \\
\text { then refrigerate or } \\
\text { freeze }\end{array}$ & $\begin{array}{c}\text { Ambient } \\
\text { temperature } \\
\text { except during } \\
\text { summer months }\end{array}$ \\
\hline $\begin{array}{l}\text { Plasma or } \\
\text { serum }\end{array}$ & $\begin{array}{l}\text { Cholesterol, lipids } \\
\text { C-reactive protein } \\
\text { Interleukins } \\
\text { ACTH } \\
\text { DHEAS }\end{array}$ & $\begin{array}{l}\text { Fasting samples } \\
\text { are often } \\
\text { required, } \\
\text { requires a } \\
\text { centrifuge }\end{array}$ & $\begin{array}{l}\text { Minimal, freeze right } \\
\text { away for some analytes } \\
\text { (e.g. ACTH) }\end{array}$ & $\begin{array}{l}\text { Frozen, at }-70^{\circ} \mathrm{C} \text { or } \\
-20^{\circ} \mathrm{C} \text { depending } \\
\text { on assay }\end{array}$ & Dry ice \\
\hline Saliva & $\begin{array}{c}\text { Cortisol } \\
\text { Interleukins }\end{array}$ & $\begin{array}{c}\text { Freeze to } \\
\text { prevent bacterial } \\
\text { growth, collect } \\
\text { at same time of } \\
\text { day }\end{array}$ & None & $\begin{array}{l}\text { Refrigerate for } \\
\text { short duration }(<1 \\
\text { day), then freeze }\end{array}$ & Dry ice \\
\hline Biopsies & $\begin{array}{l}\text { Oxidative damage } \\
\text { Inflammatory markers } \\
\text { Gene expression }\end{array}$ & $\begin{array}{l}\text { Requires trained } \\
\text { clinician }\end{array}$ & $\begin{array}{c}\text { Critical to freeze or } \\
\text { process right away with } \\
\text { antioxidants or enzyme } \\
\text { inhibitors }\end{array}$ & $\begin{array}{c}\text { Frozen, generally at } \\
-70^{\circ} \mathrm{C}\end{array}$ & Dry ice \\
\hline
\end{tabular}

has been linked to reduced activity and therefore might increase cancer risk. Despite this, epidemiological studies have generally estimated either no association or a positive association with respect to the Alanine allele, for example [194196]. In Hispanics, the Alanine substitution was more common than in whites and was associated with increased earlyonset colon cancer [197].

As none of the genes of the BER and detoxification pathways work in isolation, it is not surprising that epidemi- ologic studies of cancer risk with individual polymorphisms have been mixed. Associations may be more likely to be detected by taking a pathway-based approach and considering the cumulative number of variant polymorphisms across genes of the oxidative stress pathway, or by considering specific, biologically plausible gene-gene interactions [189, 198-200]. Given the large number of genes and SNPs involved, a composite measure needs to be developed to control for individual capacity to form and repair oxidative DNA damage. 


\section{LOGISTICS AND FEASIBILITY OF SAMPLING FOR BIOMARKERS IN HEALTH DISPARATE POPULA- TIONS}

As noted in this review, there are a number of possible biological markers of psychological stress that may be useful in understanding health disparities. However, populations suffering from higher rates of morbidity and mortality often lack community resources that facilitate collection of biological samples. Logistical issues such as study participant preparation before sampling, sample source, processing after sample collection, shipping requirements, and storage of sample are all critical in having a reliable and valid result, but dealing with these issues may be problematic in remote or economically-depressed communities. A common strategy to address these issues has been to require study participants to visit a clinical or research site. This approach raises new barriers to study participation and sample collection. For some biomarkers, simpler sampling methods have therefore been developed. In Table 1, we summarize the required handling needed for biomarkers that have been used for measures of allostatic load, immune function and oxidative stress.

The handling requirements for accurate biomarker determination have resulted in many practical issues that need to be addressed when working in the field, be it in isolated rural areas or in community clinics with limited resources. Although many research studies are initiated at large, university-associated medical centers, potential study participants may be hesitant to visit a site convenient for the study investigators due to previous negative health care experiences, lack of transportation, and mistrust of the research center. Therefore, community clinics can be used to collect the biological samples. These clinics may however lack the resources for sample processing, storage and shipping. Researchers will need to anticipate purchase of small freezers for research samples if freezing is required, or the purchase of a swinging bucket centrifuge if white cells are required. In addition, research staff may need to be present at the clinic to provide proper sample processing. Lack of a dry ice source for proper shipping of samples can also be an issue in isolated rural areas and protocols may need to be modified so that only stable biomarkers are included in the research design. In urban settings, mobile sample collection services are often available, but again sample processing may be an issue.

For collection of DNA for genotype determinations, large dried whole blood spots on FTA Cards from Whatman (Clifton, NJ) can be used. After spotting the blood on the filter paper and drying it, DNA is extracted from a standard size punched-out circle. Cell membranes and organelles are lysed, and the released nucleic acids are entrapped in the fibers of the card. The nucleic acids remain immobilized and are stabilized for transport, immediate processing or longterm room temperature storage. Since captured nucleic acids are stabilized, FTA Cards facilitate sample collection in remote locations and simplify sample transport. Other analyses can also be conducted using blood collected on filter paper cards. For example, C-reactive protein has been analyzed using blood on standardized filter papers (filter \#903, Scleicher and Schuell, Keene, NH). Staff must be trained to spot the blood properly, but once the blood is dried it can be stored at ambient temperatures for 1-2 weeks, depending on the assay. Assays are conducted using punched-out pieces of the filter paper to give a consistent assay volume for each sample [201].

\section{CONCLUSIONS}

Biomarkers have been associated with the health disparities that occur in population groups defined by SES, ethnicity and/or race and the etiology of these health disparities includes psychological stress. Psychological stress can be manifested in a number of biological markers. One summary measure of the cumulative biological burden of stress is termed allostatic load, and includes effects on the hypothalamic-pituitary axis, the sympathetic nervous system and the cardiovascular system. Allostatic stress in turn affects the immune system via bidirectional signaling pathways, and together these effects contribute to increased risks of many disease processes and susceptibility to viral infections such as AIDS. Psychological stress also can increase oxidative stress levels and DNA damage, and this may interact with genotype to modulate cancer risk. In the assessment of these biomarkers, sample collection is an important consideration and physical resources for this type of research are often limited in the field. These biomarkers of psychological stress can, however, be quite useful towards gaining a better understanding of the etiology of disease in populations subjects to health disparities.

\section{ENDNOTES}

References to race and ethnicity are made using the same designations given in the corresponding literature citations.

\section{ACKNOWLEDGEMENTS}

This work was supported by the Centers for Population Health and Health Disparities, grant numbers P50 ES012395 (Wayne State University, Detroit), P50 ES012383 (Rand Corp., Santa Monica, CA), P50 CA105631 (University of Texas, Galveston), P50 CA106743 (University of Illinois, Chicago), P50 CA105632 (Ohio State University, Columbus), P01 AG023394 (Tufts University, Boston, MA), and P50 ES012382 (University of Chicago).

\section{REFERENCES}

[1] National Institutes of Health, NIH strategic research plan to reduce and ultimately eliminate health disparities. Bethesda, MD: U.S. Department of Health and Human Services 2000.

[2] Marmot M, Wilkinson RG, Eds. Social determinants of health. $2^{\text {nd }}$ ed. Oxford: Oxford University Press 2006.

[3] Centers for disease control, health disparities exeperienced by racia/ethnic minority populations, in morbidity and mortality weekly report. Department of Health and Human Services 2005.

[4] Woolf SH, Johnson RE, Fryer GE Jr, Rust G, Satcher D. The health impact of resolving racial disparities: an analysis of US mortality data. Am J Public Health 2004; 94: 2078-81.

[5] Centers for disease control, health disparities experienced by american indians and alaska natives, in morbidity and mortality weekly Report 2003; pp. 701-706.

[6] Mensah GA, Mokdad AH, Ford ES, Greenlund KJ, Croft JB. State of disparities in cardiovascular health in the united states. Circulation 2005; 111: 1233-41.

[7] Centers for disease control, health disparities experienced by black or african americans, in morbidity and mortality weekly Report 2005; pp. 1-3.

[8] Cantwell MF, McKenna MT, McCray E, Onorato IM. Tuberculosis and race/ethnicity in the United States: impact of socioeconomic status. Am J Respir Crit Care Med 1997; 157: 1016-20.

[9] Centers for disease control, health disparities experienced by Hispanics, in morbidity and mortality Weekly Report 2004; pp. 935937. 
[10] Zhang Q, Wang Y. Trends in the association between obesity and socioeconomic status in U.S. adults: 1971 to 2000. Obes Res 2004; 12: $1622-32$.

[11] Chang VW, Lauderdale DS. Income disparities in body mass index and obesity in the United States, 1971-2002. Arch Intern Med 2005; 165: 2122-8.

[12] Keppel KG. Ten largest racial and ethnic health disparities in the United States based on healthy people 2010 Objectives. Am J Epidemiol 2007; 166: 97-103.

[13] Ward E, Jemal A, Cokkinides V, et al. Cancer disparities by race/ethnicity and socioeconomic status. CA Cancer J Clin 2004; 54: 78-93.

[14] McGinnis JM, Williams-Russo P, Knickman JR. The case for more active policy attention to health promotion. Health Affairs 2002; 21: 78-93.

[15] Soler-Vila H, Kasl SV, Jones BA. Cancer-specific beliefs and survival: a population-based study of African-American and White breast cancer patients. Cancer Causes Control 2005; 16: 105-14.

[16] Soler-Vila H, Kasl SV, Jones BA. Prognostic significance of psychosocial factors in African-American and white breast cancer patients: a population-based study. Cancer 2003; 98: 1299-308.

[17] Taylor TR, Williams CD, Makambi KH, et al. Racial discrimination and breast cancer incidence in US Black Women: The black women's health study. Am J Epidemiol 2007; 166: 46-54.

[18] Turner RJ, Avison WR. Status variations in stress exposure: implications for the interpretation of research on race, socioeconomic status, and gender. J Health Soc Behav 2003; 44: 488-505.

[19] Kessler RC. Stress, social status, and psychological distress. J Health Soc Behav 1979; 20: 259-72.

[20] Peters RM. Racism and hypertension among African Americans. West J Nurs Res 2004; 26: 612-31.

[21] Brown DJ. Everyday life for black american adults: stress, emotions, and blood pressure. West J Nurs Res 2004; 26: 499-514.

[22] Brondolo E, Rieppi R, Kelly KP, Gerin W. Perceived racism and blood pressure: a review of the literature and conceptual and methodological critique. Ann Behav Med 2003; 25: 55-65.

[23] Clark R, Anderson NB, Clark VR, Williams DR. Racism as a stressor for African Americans. A biopsychosocial model. Am Psychol 1999; 54: 805-16.

[24] James SA, Kleinbaum DG. Socioecologic stress and hypertension related mortality rates in North Carolina. Am J Public Health 1976; 66: 354-8.

[25] Aneshensel CS, Pearlin LI. In: Barnett RC, Biener L, Baruch GK, Eds. Structural contexts of sex differences in stress, Ch. 3. Gender and Stress. New York: The Free Press 1987.

[26] Catalano R. The health effects of economic insecurity. Am J Public Health 1991; 81: 1148-1152.

[27] Cannon W. The Wisdom of the Body. New York: WW Norton and Co. 1939.

[28] Sterling P, Eyer J. In: Fisher S, Reason J, Eds. Allostasis: A new paradigm to explain arousal pathology. Handbook of Life Stress, Cognition and Health. New York: John Wiley \& Sons 1988.

[29] McEwen BS. Stress, adaptation, and disease: allostasis and allostatic load. Ann N Y Acad Sci 1998; 840: 33-44.

[30] Seeman TE, Crimmins E. Social environment effects on health and aging: integrating epidemiologic and demographic approaches and perspectives. Ann N Y Acad Sci 2001; 954: 88-117.

[31] McEwen BS, Stellar E. Stress and the individual: mechanisms leading to disease. Arch Intern Med 1993; 153: 2093-2101.

[32] Araneo B, Daynes R. Dehydroepiandrosterone functions as more than an antiglucocorticoid in preserving immunocompetence after thermal injury. Endocrinology 1995; 136: 393-401.

[33] Geronimus AT, Hicken M, Keene D, Bound J. "Weathering" and age patterns of allostatic load scores among blacks and whites in the United States. Am J Public Health 2006; 96: 826-33.

[34] Tucker KL. Stress and nutrition in relation to excess development of chronic disease in Puerto Rican adults living in the Northeastern USA. J Med Invest 2005; (52 Suppl): 252-8.

[35] Oliver G, Wardle J, Gibson EL. Stress and food choice: a laboratory study. Psychosom Med 2000; 62: 853-65.

[36] Ludwig DS, Ebbeling CB, Pereira MA, Pawlak DB. A physiological basis for disparities in diabetes and heart disease risk among racial and ethnic groups. J Nutr 2002; 132: 2492-3.

[37] Appel LJ, Moore TJ, Obarzanek E, et al. A clinical trial of the effects of dietary patterns on blood pressure. DASH Collaborative Research Group. N Engl J Med 1997; 336: 1117-24.
[38] Sacks FM, Svetkey LP, Vollmer WM, et al. Effects on blood pressure of reduced dietary sodium and the Dietary Approaches to Stop Hypertension (DASH) diet. DASH-Sodium Collaborative Research Group. N Engl J Med 2001; 344: 3-10.

[39] Block G, Dietrich M, Norkus EP, et al. Factors associated with oxidative stress in human populations. Am J Epidemiol 2002; 156 : 274-85.

[40] Solzbach U, Hornig B, Jeserich M, Just H. Vitamin C improves endothelial dysfunction of epicardial coronary arteries in hypertensive patients. Circulation 1997; 96: 1513-9.

[41] Jeserich M, Schindler T, Olschewski M, Unmussig M, Just H, Solzbach U. Vitamin C improves endothelial function of epicardial coronary arteries in patients with hypercholesterolaemia or essential hypertension--assessed by cold pressor testing. Eur Heart J 1999; 20: 1676-80.

[42] Levine GN, Frei B, Koulouris SN, Gerhard MD, Keaney JF Jr, Vita JA. Ascorbic acid reverses endothelial vasomotor dysfunction in patients with coronary artery disease. Circulation 1996; 93: 110713.

[43] Felker B, Hubbard J. In: Hubbard JR, Workman EA, Eds. Influence of Mental Stress on the Endocrine System. Handbook of Stress Medicine: An Organ System Approach. New York: CRC 1998.

[44] Lundberg U. In: Fink G, Ed. Catecholamines. Encyclopedia of Stress. New York: Academic Press 2000.

[45] Guyton AC, Hall JE. In: Guyton AC, Hall JE, Eds. The Autonomic Nervous System and the Adrenal Medulla. Textbook of Medical Physiology. Philadelphia: WB Saunders 2000.

[46] McEwen BS. Protective and damaging effects of stress mediators: the good and bad sides of the response to stress. Metabolism 2002; 51:2-4.

[47] Munck A, Guyre P. Glucocorticoid physiology, pharmacology and stress. Adv Exp Med Biol 1986; 196: 81-96.

[48] Stewart PM. In: Larsen PR, Kronenberg HM, Melmed S, Polonsky KS, Eds. The Adrenal Cortex. Williams Textbook of Endocrinology. Philadelphia: Saunders 2003.

[49] Van Cauter E, Turek F. In: DeGroot L, Ed. Endocrine and other biological rhythms. Endocrinology. Philadelphia: WB Saunders 1995.

[50] Munck A. In: Fink G, Ed. Corticosteroids and Stress. Encyclopedia of Stress. New York: Academic Press 2000.

[51] McEwen BS, Biron CA, Brunson KW, et al. The role of adrenocorticoids as modulators of immune function in health and disease: neural, endocrine and immune interactions. Brain Res Brain Res Rev 1997; 23: 79-133.

[52] Rebuffe-Scrive M, Krotkiewski M, Elfverson J, Bjortorp P. Muscle and adipose morphology and metabolism in Cushing's syndrome. J Clin Endocrinol Metab 1988; 67: 1122-1128.

[53] Dallman M, Pecoraro N, Akana S, et al. Chronic stress and obesity: A new view of "comfort food". Proc Natl Acad Sci USA 2003; 100: 11696-11701.

[54] Qhinkler M, Stewart PM. Hypertension and the cortisol-cortisone shuttle. J Clin Endocrinol Metab 2003; 88: 2384-2392.

[55] Canalis E. Clinical review 83: mechanisms of glucocorticoid action in bone: implications to glucocorticoid-induced osteoporosis. J Clin Endocrinol Metab 1996; 81: 3441-3447.

[56] Sapolsky R, Krey L, McEwen B. Prolonged glucocorticoid exposure reduces hippocamppal neuron number: implications for aging. J Neurosci 1985; 5: 1222-1227.

[57] Quirarte GL, Roozendaal B, McGaugh JL. Glucocorticoid enhancement of memory storage involves noradrenergic activation in the basolateral amygdala. Proc Natl Acad Sci USA 1997; 94 14048-53.

[58] Heim C, Newport D, Heit S, et al. Pituitary-adrenal and autonomic responses to stress in women after sexual and physical abuse in childhood. JAMA 2000; 284: 592-597.

[59] Kaplan GA, Salonen JT. Socioeconomic conditions in childhood and ischaemic heart disease during middle age. BMJ 1990; 301: 1121-1123.

[60] Dallman M, Bhatnagar S, Viau V. In: Fink G, Ed. HypothalamoPituitary-Adrenal Axis. Encyclopedia of Stress. New York: Academic Press 2000.

[61] Reuben D, Talvi S, Rowe J, Seeman T. High urinary catecholamine excretion predicts mortality and functional decline in highfunctioning community-dwelling older persons: MacArthur Studies of Successful Aging. J Gerontol Series A Biol Sci Med Sci 2000; 55: M618-M624. 
[62] Goldstein DS. Plasma catecholamines in clinical studies of cardiovascular disease. Acta Physiol Scand 1984; 527: 39-41.

[63] Christensen N, Schults-Larsen K. Resting venous plasma adrenaline in 70-year men correlated positively to survival in a population study: the significance of the physical working capacity. J Intern Med 1994; 235: 229-232.

[64] Semeraro C, Marchini F, Ferlenga P, et al. The role of dopaminergic agonists in congestive heart failure. Clin Exp Hypertens 1997; 19: 201-215.

[65] Kirschbaum C, Hellhammer DH. In: Fink G, Ed. Salivary cortisol. Encyclopedia of Stress. New York: Academic Press 2000.

[66] Dickerson S, Kemeny M. Acute stressors and cortisol responses: A theoretical integration and synthesis of laboratory research. Pscychol Bull 2004; 130: 355-391.

[67] Greenberg GN, Levine RJ. Urinary excretion is not stable: a new method for assessing urinary toxic substance concentration. J Occup Med 1989; 31: 832-838.

[68] Goldwasser P, Aboul-Magd A, Maru M. Race and creatinine excretion in chronic renal insufficiency. Am J Kidney Dis 1997; 30: 1622.

[69] Masi C, Rickett E, Hawkley L, Cacioppo J. Gender and ethnic differences in urinary stress hormones: The population-based Chicago health, aging, and social relations study. J Appl Physiol 2004; 97: 941-947.

[70] Okumura T, Nakajima Y, Matsuoka M, Takamatsu T. Study of salivary catecholamines using fully automated column-switching high-performanc liquid chromatography. J Chromatogr B Biomed Sci Appl 1997; 694: 305-316.

[71] Christensen N, Jensen E. Sympathoadrenal activity and psychosocial stress. Ann N Y Acad Sci 1995; 771: 640-646.

[72] Blalock JE, Harbour-McMenamin D, Smith EM. Peptide hormones shared by the neuroendocrine and immunologic systems. J Immunol 1985; 135: 858s-861s.

[73] Besedovsky HO, del Rey A. The cytokine-HPA axis feed-back circuit. Z Rheumatol 2000; 59 (Suppl 2): II/26-30.

[74] Besedovsky H, del Rey A, Sorkin E, Da Prada M, Burri R, Hosegger $\mathrm{C}$. The immune response evokes changes in brain noradenergic neurons. Science 1983; 221: 564-565.

[75] Smith EM, Meyer WJ, Blalock JE. Virus-induced corticosterone in hypophysectomized mice: a possible lymphoid adrenal axis. Science 1982; 218: 1311-2.

[76] Fauci AS, Dale DC. Alternate-day prednisone therapy and human lymphocyte subpopulations. J Clin Invest 1975; 55: 22-32.

[77] Fauci AS, Dale DC, Balow JE. Glucocorticosteroid therapy: mechanisms of action and clinical considerations. Ann Intern Med 1976; 84: 304-15.

[78] Dhabhar FS, Miller AH, McEwen BS, Spencer RL. Effects of stress on immune cell distribution. Dynamics and hormonal mechanisms. J Immunol 1995; 154: 5511-27.

[79] Blotta MH, DeKruyff RH, Umetsu DT. Corticosteroids inhibit IL12 production in human monocytes and enhance their capacity to induce IL-4 synthesis in CD4+ lymphocytes. J Immunol 1997; 158: 5589-95.

[80] DeKruyff RH, Fang Y, Umetsu DT. Corticosteroids enhance the capacity of macrophages to induce Th2 cytokine synthesis in CD4+ lymphocytes by inhibiting IL-12 production. J Immunol 1998; 160: 2231-7.

[81] Elenkov IJ, Papanicolaou DA, Wilder RL, Chrousos GP. Modulatory effects of glucocorticoids and catecholamines on human interleukin-12 and interleukin-10 production: clinical implications. Proc Assoc Am Physicians 1996; 108: 374-81.

[82] Elenkov IJ, Chrousos GP. Stress hormones, proinflammatory and antiinflammatory cytokines, and autoimmunity. Ann N Y Acad Sci 2002; 966: 290-303.

[83] Auphan N, DiDonato JA, Rosette C, Helmberg A, Karin M. Immunosuppression by glucocorticoids: inhibition of NF-kappa B activity through induction of I kappa B synthesis. Science 1995; 270: 286-90.

[84] Scheinman RI, Cogswell PC, Lofquist AK, Baldwin AS, Jr. Role of transcriptional activation of I kappa B alpha in mediation of immunosuppression by glucocorticoids. Science 1995; 270: 283-6.

[85] Blackwell TS, Christman JW. The role of nuclear factor-kappa B in cytokine gene regulation. Am J Respir Cell Mol Biol 1997; 17: 3-9.

[86] Yu DT, Clements PJ. Human lymphocyte subpopulations effect of epinephrine. Clin Exp Immunol 1976; 25: 472-9.
[87] Landmann RM, Muller FB, Perini C, Wesp M, Erne P, Buhler FR. Changes of immunoregulatory cells induced by psychological and physical stress: relationship to plasma catecholamines. Clin Exp Immunol 1984; 58: 127-35.

[88] Drews J. The pharmacology of the immune system: clinical and experimental perspectives. Prog Drug Res 1984; 28: 83-109.

[89] Crary B, Hauser SL, Borysenko M, et al. Epinephrine-induced changes in the distribution of lymphocyte subsets in peripheral blood of humans. J Immunol 1983; 131: 1178-81.

[90] Davis JM, Albert JD, Tracy KJ, et al. Increased neutrophil mobilization and decreased chemotaxis during cortisol and epinephrine infusions. J Trauma 1991; 31: 725-31; discussion 731-2.

[91] Koff WC, Dunegan MA. Modulation of macrophage-mediated tumoricidal activity by neuropeptides and neurohormones. J Immunol 1985; 135: 350-4.

[92] Rozlog LA, Kiecolt-Glaser JK, Marucha PT, Sheridan JF, Glaser R. Stress and immunity: implications for viral disease and wound healing. J Periodontol 1999; 70: 786-92.

[93] Kiecolt-Glaser JK, Dura JR, Speicher CE, Trask OJ, Glaser R. Spousal caregivers of dementia victims: longitudinal changes in immunity and health. Psychosom Med 1991; 53: 345-62.

[94] Schulz R, Beach SR. Caregiving as a risk factor for mortality: the caregiver health effects study. JAMA 1999; 282: 2215-9.

[95] Asanuma Y, Chung CP, Oeser A, et al. Increased concentration of proatherogenic inflammatory cytokines in systemic lupus erythematosus: relationship to cardiovascular risk factors. J Rheumatol 2006; 33: 539-45.

[96] Lopez-Garcia E, Schulze MB, Fung TT, et al. Major dietary patterns are related to plasma concentrations of markers of inflammation and endothelial dysfunction. Am J Clin Nutr 2004; 80: 102935 .

[97] Bruunsgaard H. Physical activity and modulation of systemic lowlevel inflammation. J Leukoc Biol 2005; 78: 819-35.

[98] Ferrucci L, Harris TB, Guralnik JM, et al. Serum IL-6 level and the development of disability in older persons. J Am Geriatr Soc 1999; 47: 639-46.

[99] Vgontzas AN, Papanicolaou DA, Bixler EO, et al. Circadian interleukin-6 secretion and quantity and depth of sleep. J Clin Endocrinol Metab 1999; 84: 2603-7.

[100] Vgontzas AN, Bixler EO, Lin HM, Prolo P, Trakada G, Chrousos GP. IL-6 and its circadian secretion in humans. Neuroimmunomodulation 2005; 12: 131-40.

[101] Taaffe DR, Harris TB, Ferrucci L, Rowe J, Seeman TE. Crosssectional and prospective relationships of interleukin-6 and Creactive protein with physical performance in elderly persons: MacArthur studies of successful aging. J Gerontol A Biol Sci Med Sci 2000; 55: M709-15.

[102] Irwin M, Rinetti G, Redwine L, Motivala S, Dang J, Ehlers C. Nocturnal proinflammatory cytokine-associated sleep disturbances in abstinent African American alcoholics. Brain Behav Immun 2004; 18: 349-60.

[103] Redwine L, Hauger RL, Gillin JC, Irwin M. Effects of sleep and sleep deprivation on interleukin-6, growth hormone, cortisol, and melatonin levels in humans. J Clin Endocrinol Metab 2000; 85: 3597-603.

[104] Kiecolt-Glaser JK, McGuire L, Robles TF, Glaser R. Psychoneuroimmunology: psychological influences on immune function and health. J Consult Clin Psychol 2002; 70: 537-47.

[105] Keaney JF Jr, Vita JA. The value of inflammation for predicting unstable angina. N Engl J Med 2002; 347: 55-7.

[106] Ridker PM. C-reactive protein, inflammation, and cardiovascular disease: clinical update. Tex Heart Inst J 2005; 32: 384-6.

[107] Epel ES, Blackburn EH, Lin J, et al. Accelerated telomere shortening in response to life stress. Proc Natl Acad Sci USA 2004; 101: 17312-5.

[108] Passos JF, Saretzki G, von Zglinicki T. DNA damage in telomeres and mitochondria during cellular senescence: is there a connection? Nucleic Acids Res 2007; 35: 7505-13.

[109] Cohen S, Williamson GM. Stress and infectious disease in humans. Psychol Bull 1991; 109: 5-24.

[110] Cohen S, Frank E, Doyle WJ, Skoner DP, Rabin BS, Gwaltney JM, Jr. Types of stressors that increase susceptibility to the common cold in healthy adults. Health Psychol 1998; 17: 214-23.

[111] Stone A, Bovbjerg D, Neale J, et al. Development of common cold symptoms following experimental rhinovirus infection is related to prior stressful life events. Behav Med 1992; 18: 115-120. 
[112] Cohen S. Keynote Presentation at the eight international congress of behavioral medicine: the Pittsburgh common cold studies: psychosocial predictors of susceptibility to respiratory infectious illness. Int J Behav Med 2005; 12: 123-31.

[113] Dean HD, Steele CB, Satcher AJ, Nakashima AK. HIV/AIDS among minority races and ethnicities in the United States, 19992003. J Natl Med Assoc 2005; 97: 5S-12S.

[114] Leserman J, Jackson ED, Petitto JM, et al. Progression to AIDS: the effects of stress, depressive symptoms, and social support. Psychosom Med 1999; 61: 397-406.

[115] Cole SW, Kemeny ME, Taylor SE, Visscher BR, Fahey JL. Accelerated course of human immunodeficiency virus infection in gay men who conceal their homosexual identity. Psychosom Med 1996; 58: 219-31.

[116] Juranek I, Bezek S. Controversy of free radical hypothesis: reactive oxygen species--cause or consequence of tissue injury? Gen Physiol Biophys 2005; 24: 263-78.

[117] Bartsch H, Nair J. Oxidative stress and lipid peroxidation-derived DNA-lesions in inflammation driven carcinogenesis. Cancer Detect Prev 2004; 28: 385-91.

[118] Itzkowitz $\mathrm{SH}, \mathrm{Yio} \mathrm{X}$. Inflammation and cancer IV. Colorectal cancer in inflammatory bowel disease: the role of inflammation. Am J Physiol Gastrointest Liver Physiol 2004; 287: G7-17.

[119] Marx J. Cancer research. Inflammation and cancer: the link grows stronger. Science 2004; 306: 966-8

[120] King DE, Mainous AG $3^{\text {rd }}$, Taylor ML. Clinical use of C-reactive protein for cardiovascular disease. South Med J 2004; 97: 985-8.

[121] Stocker R, Keaney JF, Jr. Role of oxidative modifications in atherosclerosis. Physiol Rev 2004; 84: 1381-478.

[122] Madamanchi NR, Vendrov A, Runge MS. Oxidative stress and vascular disease. Arterioscler Thromb Vasc Biol 2005; 25: 29-38.

[123] Malinski T. Understanding nitric oxide physiology in the heart: a nanomedical approach. Am J Cardiol 2005; 96: 13i-24i.

[124] Fortuno A, Jose GS, Moreno MU, Diez J, Zalba G. Oxidative stress and vascular remodelling. Exp Physiol 2005; 90: 457-62.

[125] Pennathur S, Heinecke JW. Oxidative stress and endothelial dysfunction in vascular disease. Curr Diab Rep 2007; 7: 257-64.

[126] Pacher P, Obrosova IG, Mabley JG, Szabo C. Role of nitrosative stress and peroxynitrite in the pathogenesis of diabetic complications. Emerging new therapeutical strategies. Curr Med Chem 2005; 12: 267-75.

[127] Maiese K, Chong ZZ, Shang YC. Mechanistic insights into diabetes mellitus and oxidative stress. Curr Med Chem 2007; 14: 172938 .

[128] Schleicher E, Friess U. Oxidative stress, AGE, and atherosclerosis. Kidney Int Suppl 2007; 106: S17-26.

[129] Poulsen HE. Oxidative DNA modifications. Exp Toxicol Pathol 2005; 57 (Suppl 1): 161-9.

[130] Kurian AK, Cardarelli KM. Racial and ethnic differences in cardiovascular disease risk factors: a systematic review. Ethn Dis 2007; 17: 143-52.

[131] Watters JL, Satia JA, Kupper LL, Swenberg JA, Schroeder JC, Switzer BR. Associations of antioxidant nutrients and oxidative DNA damage in healthy African-American and White adults. Cancer Epidemiol Biomarkers Prev 2007; 16: 1428-36.

[132] Mason RP, Kalinowski L, Jacob RF, Jacoby AM, Malinski T. Nebivolol reduces nitroxidative stress and restores nitric oxide bioavailability in endothelium of black Americans. Circulation 2005; 112: 3795-801.

[133] Kalinowski L, Dobrucki IT, Malinski T. Race-specific differences in endothelial function: predisposition of African Americans to vascular diseases. Circulation 2004; 109: 2511-7.

[134] Goodfriend TL, Calhoun DA. Resistant hypertension, obesity, sleep apnea, and aldosterone: theory and therapy. Hypertension 2004; 43: 518-24.

[135] Lopes HF, Morrow JD, Stojiljkovic MP, Goodfriend TL, Egan BM. Acute hyperlipidemia increases oxidative stress more in African Americans than in white Americans. Am J Hypertens 2003; 16: 331-6.

[136] Ke RW, Todd Pace D, Ahokas RA. Effect of short-term hormone therapy on oxidative stress and endothelial function in African American and Caucasian postmenopausal women. Fertil Steril 2003; 79: 1118-22.

[137] American Cancer Society, Cancer Facts and Figures 2007. Atlanta, GA 2007.
[138] Gadgeel SM, Kalemkerian GP. Racial differences in lung cancer. Cancer Metastasis Rev 2003; 22: 39-46.

[139] Peters N, Armstrong K. Racial differences in prostate cancer treatment outcomes: a systematic review. Cancer Nurs 2005; 28: 10818.

[140] Rex DK, Rawl SM, Rabeneck L, Rex EK, Hamilton F. Colorectal cancer in African Americans. Rev Gastroenterol Disord 2004; 4: $60-5$

[141] Field TS, Buist DS, Doubeni C, et al. Disparities and survival among breast cancer patients. J Natl Cancer Inst Monogr 2005: 8895.

[142] Chlebowski RT, Chen Z, Anderson GL, et al. Ethnicity and breast cancer: factors influencing differences in incidence and outcome. J Natl Cancer Inst 2005; 97: 439-48.

[143] Bierhaus A, Humpert PM, Nawroth PP. NF-kappaB as a molecular link between psychosocial stress and organ dysfunction. Pediatr Nephrol 2004; 19: 1189-91.

[144] Tyagi N, Sedoris KC, Steed M, Ovechkin AV, Moshal KS, Tyagi SC. Mechanisms of homocysteine-induced oxidative stress. Am J Physiol Heart Circ Physiol 2005; 289: H2649-56.

[145] Hapuarachchi JR, Chalmers AH, Winefield AH, Blake-Mortimer JS. Changes in clinically relevant metabolites with psychological stress parameters. Behav Med 2003; 29: 52-9.

[146] Miyashita T, Yamaguchi T, Motoyama K, Unno K, Nakano Y, Shimoi K. Social stress increases biopyrrins, oxidative metabolites of bilirubin, in mouse urine. Biochem Biophys Res Commun 2006; 349: 775-80.

[147] Sivonova M, Zitnanova I, Hlincikova L, Skodacek I, Trebaticka J, Durackova Z. Oxidative stress in university students during examinations. Stress 2004; 7: 183-8.

[148] Irie M, Asami S, Nagata S, Miyata M, Kasai H. Classical conditioning of oxidative DNA damage in rats. Neurosci Lett 2000; 288 : $13-6$

[149] Irie M, Miyata M, Kasai H. Depression and possible cancer risk due to oxidative DNA damage. J Psychiatr Res 2005; 39: 553-60.

[150] Irie M, Asami S, Ikeda M, Kasai H. Depressive state relates to female oxidative DNA damage via neutrophil activation. Biochem Biophys Res Commun 2003; 311: 1014-8.

[151] Tsuboi H, Shimoi K, Kinae N, Oguni I, Hori R, Kobayashi F. Depressive symptoms are independently correlated with lipid peroxidation in a female population: comparison with vitamins and carotenoids. J Psychosom Res 2004; 56: 53-8.

[152] Miyaoka T, Yasukawa R, Yasuda H, et al. Urinary excretion of biopyrrins, oxidative metabolites of bilirubin, increases in patients with psychiatric disorders. Eur Neuropsychopharmacol 2005; 15: 249-52.

[153] Blazer DG, Moody-Ayers S, Craft-Morgan J, Burchett B. Depression in diabetes and obesity: racial/ethnic/gender issues in older adults. J Psychosom Res 2002; 53: 913-6.

[154] Baltrus PT, Lynch JW, Everson-Rose S, Raghunathan TE, Kaplan GA. Race/ethnicity, life-course socioeconomic position, and body weight trajectories over 34 years: the Alameda county study. Am J Public Health 2005; 95: 1595-601.

[155] Kristenson M, Eriksen HR, Sluiter JK, Starke D, Ursin H. Psychobiological mechanisms of socioeconomic differences in health. Soc Sci Med 2004; 58: 1511-22.

[156] Skarupski KA, Mendes de Leon CF, Bienias JL, et al. Black-white differences in depressive symptoms among older adults over time. J Gerontol B Psychol Sci Soc Sci 2005; 60: P136-42.

[157] Henderson C, Diez Roux AV, Jacobs DR Jr, Kiefe CI, West D, Williams DR. Neighbourhood characteristics, individual level socioeconomic factors, and depressive symptoms in young adults: the CARDIA study. J Epidemiol Community Health 2005; 59: 322-8.

[158] Strike PC, Steptoe A. Psychosocial factors in the development of coronary artery disease. Prog Cardiovasc Dis 2004; 46: 337-47.

[159] Ren XS, Amick BC. Racial and ethnic disparities in self-assessed health status: evidence from the national survey of families and households. Ethn Health 1996; 1: 293-303.

[160] Pajovic SB, Pejic S, Stojiljkovic V, Gavrilovic L, Dronjak S, Kanazir DT. Alterations in hippocampal antioxidant enzyme activities and sympatho-adrenomedullary system of rats in response to different stress models. Physiol Res 2006; 55(4): 453-60.

[161] Matsumoto K, Yobimoto K, Huong NT, Abdel-Fattah M, Van Hien T, Watanabe H. Psychological stress-induced enhancement of brain lipid peroxidation via nitric oxide systems and its modulation by 
anxiolytic and anxiogenic drugs in mice. Brain Res 1999; 839: 7484.

[162] Srikumar R, Parthasarathy NJ, Manikandan S, Narayanan GS, Sheeladevi R. Effect of Triphala on oxidative stress and on cellmediated immune response against noise stress in rats. Mol Cell Biochem 2006; 283: 67-74.

[163] Adachi S, Kawamura K, Takemoto K. Oxidative damage of nuclear DNA in liver of rats exposed to psychological stress. Cancer Res 1993; 53: 4153-5.

[164] Irie M, Asami S, Nagata S, Miyata M, Kasai H. Psychological mediation of a type of oxidative DNA damage, 8-hydroxydeoxyguanosine, in peripheral blood leukocytes of non-smoking and non-drinking workers. Psychother Psychosom 2002; 71: 90-6.

[165] Sanchez-Rodriguez MA, Retana-Ugalde R, Ruiz-Ramos M, Munoz-Sanchez JL, Vargas-Guadarrama LA, Mendoza-Nunez VM. Efficient antioxidant capacity against lipid peroxide levels in healthy elderly of Mexico City. Environ Res 2005; 97: 322-9.

[166] Sanchez-Rodriguez MA, Santiago E, Arronte-Rosales A, VargasGuadarrama LA, Mendoza-Nunez VM. Relationship between oxidative stress and cognitive impairment in the elderly of rural vs. urban communities. Life Sci 2006; 78: 1682-7.

[167] Irie M, Asami S, Nagata S, Miyata M, Kasai H. Relationships between perceived workload, stress and oxidative DNA damage. Int Arch Occup Environ Health 2001; 74: 153-7.

[168] Irie M, Asami S, Nagata S, Ikeda M, Miyata M, Kasai H. Psychosocial factors as a potential trigger of oxidative DNA damage in human leukocytes. Jpn J Cancer Res 2001; 92: 367-76.

[169] Grossi G, Perski A, Evengard B, Blomkvist V, Orth-Gomer K. Physiological correlates of burnout among women. J Psychosom Res 2003; 55: 309-16.

[170] Tucker P, Rutherford C. Moderators of the relationship between long work hours and health. J Occup Health Psychol 2005; 10: 46576.

[171] Shinmura K, Yokota J. The OGG1 gene encodes a repair enzyme for oxidatively damaged DNA and is involved in human carcinogenesis. Antioxid Redox Signal 2001; 3: 597-609.

[172] Izumi T, Wiederhold LR, Roy G, et al. Mammalian DNA base excision repair proteins: their interactions and role in repair of oxidative DNA damage. Toxicology 2003; 193: 43-65.

[173] Yoon JH, Iwai S, O'Connor TR, Pfeifer GP. Human thymine DNA glycosylase (TDG) and methyl-CpG-binding protein 4 (MBD4) excise thymine glycol (Tg) from a Tg:G mispair. Nucleic Acids Res 2003; 31: 5399-404.

[174] Mitra S, Boldogh I, Izumi T, Hazra TK. Complexities of the DNA base excision repair pathway for repair of oxidative DNA damage. Environ Mol Mutagen 2001; 38: 180-90.

[175] Mol CD, Hosfield DJ, Tainer JA. Abasic site recognition by two apurinic/apyrimidinic endonuclease families in DNA base excision repair: the 3' ends justify the means. Mutat Res 2000; 460: 211-29.

[176] Ladiges W, Wiley J, MacAuley A. Polymorphisms in the DNA repair gene XRCC1 and age-related disease. Mech Ageing Dev 2003; 124: 27-32.

[177] Chen L, Ambrosone CB, Lee J, Sellers TA, Pow-Sang J, Park JY. Association between polymorphisms in the DNA repair genes XRCC1 and APE1, and the risk of prostate cancer in white and black Americans. J Urol 2006; 175: 108-12; discussion 112.

[178] Mechanic LE, Millikan RC, Player J, et al. Polymorphisms in nucleotide excision repair genes, smoking and breast cancer in African Americans and whites: a population-based case-control study. Carcinogenesis 2006; 27: 1377-85.

[179] Yamane A, Kohno T, Ito K, et al. Differential ability of polymorphic OGG1 proteins to suppress mutagenesis induced by 8 hydroxyguanine in human cell in vivo. Carcinogenesis 2004; 25 : 1689-94.

[180] Sugimura H, Kohno T, Wakai K, et al. hOGG1 Ser326Cys polymorphism and lung cancer susceptibility. Cancer Epidemiol Biomarkers Prev 1999; 8: 669-74.

[181] Choi JY, Hamajima N, Tajima K, et al. hOGG1 Ser326Cys polymorphism and breast cancer risk among Asian women. Breast Cancer Res Treat 2003; 79: 59-62.
[182] Xing D, Tan W, Lin D. Genetic polymorphisms and susceptibility to esophageal cancer among Chinese population (review). Oncol Rep 2003; 10: 1615-23.

[183] Xu J, Zheng SL, Turner A, et al. Associations between hOGG1 sequence variants and prostate cancer susceptibility. Cancer Res 2002; 62: 2253-7.

[184] National Institutes of Environmental Health. NIEHS SNPs. NIEHS Environmental Genome Project. 2006 [cited March 23, 2006].

[185] Lamerdin JE, Montgomery MA, Stilwagen SA, et al. Genomic sequence comparison of the human and mouse XRCC1 DNA repair gene regions. Genomics 1995; 25: 547-54.

[186] Chacko P, Rajan B, Joseph T, Mathew BS, Pillai MR. Polymorphisms in DNA repair gene XRCC1 and increased genetic susceptibility to breast cancer. Breast Cancer Res Treat 2005; 89: 15-21.

[187] Duell EJ, Millikan RC, Pittman GS, et al. Polymorphisms in the DNA repair gene XRCC1 and breast cancer. Cancer Epidemiol Biomarkers Prev 2001; 10: 217-22.

[188] Fortini P, Pascucci B, Parlanti E, D'Errico M, Simonelli V, Dogliotti E. 8-Oxoguanine DNA damage: at the crossroad of alternative repair pathways. Mutat Res 2003; 531: 127-39.

[189] Smith TR, Miller MS, Lohman K, et al. Polymorphisms of XRCC1 and XRCC3 genes and susceptibility to breast cancer. Cancer Lett 2003; 190: 183-90.

[190] Hu JJ, Smith TR, Miller MS, Mohrenweiser HW, Golden A, Case LD. Amino acid substitution variants of APE1 and XRCC1 genes associated with ionizing radiation sensitivity. Carcinogenesis 2001; 22: 917-22.

[191] Shen M, Berndt SI, Rothman N, et al. Polymorphisms in the DNA base excision repair genes APEX1 and XRCC1 and lung cancer risk in Xuan Wei, China. Anticancer Res 2005; 25: 537-42.

[192] Lockett KL, Snowhite IV, Hu JJ. Nucleotide-excision repair and prostate cancer risk. Cancer Lett 2005; 220: 125-35

[193] Kumar R, Hoglund L, Zhao C, Forsti A, Snellman E, Hemminki K. Single nucleotide polymorphisms in the XPG gene: determination of role in DNA repair and breast cancer risk. Int J Cancer 2003; 103: 671-5.

[194] Ambrosone CB, Freudenheim JL, Thompson PA, et al. Manganese superoxide dismutase (MnSOD) genetic polymorphisms, dietary antioxidants, and risk of breast cancer. Cancer Res 1999; 59: 602-6.

[195] Kang D, Lee KM, Park SK, et al. Functional variant of manganese superoxide dismutase (SOD2 V16A) polymorphism is associated with prostate cancer risk in the prostate, lung, colorectal, and ovarian cancer study. Cancer Epidemiol Biomarkers Prev 2007; 16 : 1581-6.

[196] Slanger TE, Chang-Claude J, Wang-Gohrke S. Manganese superoxide dismutase Ala-9Val polymorphism, environmental modifiers, and risk of breast cancer in a German population. Cancer Causes Control 2006; 17: 1025-31.

[197] Stoehlmacher J, Ingles SA, Park DJ, Zhang W, Lenz HJ. The 9Ala/-9Val polymorphism in the mitochondrial targeting sequence of the manganese superoxide dismutase gene (MnSOD) is associated with age among Hispanics with colorectal carcinoma. Oncol Rep 2002; 9: 235-8.

[198] Hao B, Wang H, Zhou K, et al. Identification of genetic variants in base excision repair pathway and their associations with risk of esophageal squamous cell carcinoma. Cancer Res 2004; 64: 437884.

[199] Lan Q, Zheng T, Shen M, et al. Genetic polymorphisms in the oxidative stress pathway and susceptibility to non-Hodgkin lymphoma. Hum Genet 2007; 121: 161-8.

[200] Millikan RC, Player JS, Decotret AR, Tse CK, Keku T. Polymorphisms in DNA repair genes, medical exposure to ionizing radiation, and breast cancer risk. Cancer Epidemiol Biomarkers Prev 2005; 14: 2326-34.

[201] McDade TW, Burhop J, Dohnal J. High-sensitivity enzyme immunoassay for C-reactive protein in dried blood spots. Clin Chem 2004; 50: 652-4.

(C) Djuric et al.; Licensee Bentham Open.

This is an open access article licensed under the terms of the Creative Commons Attribution Non-Commercial License (http://creativecommons.org/licenses/by-nc/3.0/) which permits unrestricted, non-commercial use, distribution and reproduction in any medium, provided the work is properly cited. 